\title{
Entrevista
}

\section{Acasos e escolhas: uma trajetória nada ortodoxa na antropologia \\ Entrevista com Armelle Giglio-Jacquemot}

\author{
Carmen Fullin-cfullin@uol.com.br \\ Juliana Tonche-jutonche@gmail.com \\ Maria Luisa Scaramella - revant@usp.br \\ Edição final de Ana Lúcia Pastore Schritzmeyer ${ }^{1}$ - alps@usp.br \\ Universidade de São Paulo, São Paulo, SP, Brasil
}

Armelle Giglio-Jacquemot é antropóloga, professora da UFR (Unité de Formation et de Recherche) de Sciences Humaines et Arts e pesquisadora do Groupe de Recherches Sociologiques sur les Sociétés Contemporaines (Gresco), ambos ligados à Universidade de Poitiers na França.

Sua produção científica é fortemente marcada por uma antropologia brasilianista e pela ampla diversidade temática, algo que escapa dos modelos mais ortodoxos de formação acadêmica. O Brasil está presente em sua produção desde seu primeiro trabalho de campo sobre o tema da doença e da cura na umbanda, feito na cidade de São Paulo, no final dos anos 1980.

A oportunidade de continuar pesquisando tais temas levou-a ao interior do estado de São Paulo, onde encontrou terreno privilegiado para realizar uma pioneira etnografia da prestação de serviços de saúde, do que resultou o livro Urgências e emergências em saúde: perspectivas de profissionais e usuários, publicado pela Fiocruz, em 2005.

Mais recentemente, estabeleceu contato com a antropologia ambiental ao aceitar o desafio de direcionar suas pesquisas rumo ao Nordeste do país para tratar de um tema estratégico do ponto de vista geopolítico, mas ainda pouco estudado em perspectiva etnográfica: a dimensão cultural do uso de recursos hídricos em cenários de escassez. 
Foi esse, aliás, o tema de sua conferência no IV Enadir - Encontro Nacional de Antropologia do Direito, realizada no dia 26 agosto de 2015, nas dependências da Faculdade de Filosofia, Letras e Ciências Humanas da Universidade de São Paulo, FFLCH USP, oportunidade na qual esta entrevista foi realizada.

Cabe destacar suas incursóes pela antropologia do direito, área de estudos assumidamente não constitutiva de sua formação acadêmica. É nesse ponto que a trajetória de Armelle Giglio-Jacquemot se afirma como uma construção original, marcada por acasos e escolhas. Como antropóloga de ofício, no exercício daquilo que Mariza Peirano chamaria de "instinto etnográfico", a pesquisadora fez do acaso de compor o Conselho de Jurados de um Tribunal do Júri da França, uma oportunidade para explorar "a potencialidade de estranhamento, o insólito da experiência, a necessidade de examinar por que alguns eventos, vividos ou observados, nos surpreendem" (Peirano, 2014, 379) ${ }^{2}$.

O acaso - "sorte", segundo Armelle - de, em certo momento, ter tido uma filmadora disponível, aliado à percepção do potencial etnográfico contido na gravação de imagens também lhe permitiram acumular contribuições importantes na área da antropologia visual, registradas em artigos e diversos documentários mencionados nesta entrevista. Mas é no exercício de uma antropologia sem fronteiras e sem dogmatismos, características que qualificam seu percurso acadêmico, que Armelle Giglio-Jacquemot não hesita em avaliar com parcimônia o uso de certas imagens como instrumento de comunicação intercultural.

Para começar, gostaríamos que você se apresentasse e contasse um pouco a sua trajetória acadêmica e profissional na antropologia.

Nós podemos começar pela placa "Centro de Estudos Africanos", que me fez lembrar a primeira vez que vim à USP. Isso foi bem no início dos meus estudos de antropologia, quando eu estava no terceiro ano de graduação, começando a estudar umbanda. Eu vinha muito para este corredor porque, na época, nele também ficava a sala da antropóloga Liana Trindade ${ }^{3}$, que foi muito importante em meu percurso. Foi ela quem despertou meu interesse pela umbanda e também, durante anos, foi minha interlocutora privilegiada sobre esse tema. Eu a havia encontrado na França, na Universidade de Aix-en-Provence, por ocasião de uma palestra que ela proferiu sobre as religióes afro-brasileiras no curso 
"Magistère en Sciences Sociales". Fiquei muito interessada e foi a antropologia da religião que transformou totalmente a minha percepção de religião como "ópio do povo". Foi por meio desse curso de três anos que aprendi português e consegui uma bolsa que me permitiu viajar pela primeira vez ao Brasil. Meu único contato acadêmico era com Liana. Daí tantas lembranças a partir do Centro de Estudos Africanos, mesmo passados 28 anos.

Naquela época, havia na França poucas referências à umbanda além das pesquisas de Roger Bastide, de seus escritos mais baseados em uma literatura umbandista que propriamente em trabalhos de campo ${ }^{4}$. Havia também a tese de Renato Ortiz, defendida na EHESS de Paris, em 1975, La Mort blanche du sorcier noir. Eu vim ao Brasil com a intenção de fazer o meu primeiro trabalho de campo e, com indicações de Liana, comecei a frequentar um terreiro em Pinheiros. Uma descoberta levou a outra, aprofundei meus conhecimentos sobre religião e o Brasil, e assim cheguei à minha tese de doutorado sobre a doença na umbanda ${ }^{6}$. Ao todo, foram mais de 10 anos estudando umbanda ${ }^{7}$.

O que nos chama a atenção em sua trajetória é a diversidade temática. Aqui no Brasil, geralmente se recomenda o aprofundamento em um campo de pesquisa. O que você pensa a esse respeito?

Minha trajetória acadêmica pode não parecer muito ortodoxa e certamente não o é, pois explorei realidades, campos e questóes que perpassam diversas áreas da antropologia. Mas ao observar meu percurso, vejo que houve uma continuidade, pois cada passo que dei foi motivado pelos anteriores. As incursôes que fiz em áreas diversas da antropologia sempre foram devidas ao aprofundamento ou ao despertar para questôes que surgiram no campo.

Assim como muitos antropólogos, fui levada a me interessar por questóes de saúde, doença e cura através de pesquisas iniciadas no campo da antropologia da religiáo. Quando comecei a estudar umbanda, com a intenção primeira de decifrar um universo religioso empiricamente ainda pouco conhecido, descobri o papel central que a doença, sua interpretação e seu tratamento tinham para os envolvidos. Aprofundei esse dado no doutorado, tentando entender o significado da doença na umbanda e, durante um bom tempo, me interessei pela relação estreita que une saúde e religião, atestada em todas as sociedades do mundo. $\mathrm{O}$ meu orientador foi Jean Benoist, um pesquisador também pouco ortodoxo, grande professor, médico e antropólogo. Ele tinha uma atuação pouco 
convencional na pós-graduação, por aceitar médicos que queriam se formar em antropologia médica, o que academicamente era incomum e até reprovado ${ }^{8}$.

A partir desse primeiro interesse pela doença e pela saúde, despertado de maneira inesperada por um universo religioso em que eu só esperava encontrar "religiosidade", fui levada, por meio da abordagem do pluralismo médico, a investigar outros universos nos quais a dimensão religiosa não é manifesta nem é reivindicada por seus participantes. Foi o caso de minhas pesquisas sobre prontos-socorros e as noçóes de urgência e emergência?

Com os temas da urgência e da emergência eu encontrei o SAMU. ${ }^{10}$. Naquele momento, uma concepção de urgência à francesa estava se espalhando pelo mundo, mas já se tinha noção de que era preciso ter elementos de compreensão dos universos culturais em que essas políticas de saúde estavam se implantando. O SAMU de Paris pagou a minha primeira missão na cidade de São Paulo, onde fui colocada em contato com pessoas da Secretaria de Saúde e comecei o trabalho de campo no pronto-socorro do Hospital das Clínicas. Era mais um campo exploratório que durou uns quinze dias. Por ocasiáo dessa mesma missão, conheci a professora Maria Cecília Dellatorre ${ }^{11}$, docente da Faculdade de Medicina de Marília, Famema, que trabalhava com saúde preventiva e também tinha relaçóes com o SAMU de Paris. Em Marília, ela me colocou em contato com um sistema de atendimento às urgências, ocasião em que me convenci de que essa cidade seria o melhor lugar para desenvolver a pesquisa. Eu fiz a proposta ao departamento de antropologia e de sociologia da Faculdade de Filosofia e Ciências de Marília e, aproximadamente um ano depois, me contataram para desenvolvermos um projeto que consegui levar adiante graças a uma bolsa de pós-doutorado concedida pela Fapesp. Foi assim que passei um ano em Marília, fazendo trabalho de campo sobre urgências e emergências, nos prontos-socorros do Hospital das Clínicas e da Santa Casa, no SAMU e nos bombeiros.

Por que você achou que Marilia seria o melhor lugar para desenvolver a pesquisa?

Primeiro porque havia pessoas, na saúde preventiva, muito envolvidas com saúde pública e com o tema das urgências e eu podia trabalhar com esse grupo. Foi com ele e graças a ele que eu obtive autorizaçóes para fazer o trabalho de campo. Eu me interessava pela categoria "urgência”. Eu podia imaginar, pelas minhas pesquisas anteriores, que seu conteúdo variaria em função de distintas perspectivas e posiçóes. Eu pensei na antropologia da doença e no 
que nós conceituamos, a partir de estudos norte-americanos, como disease, e illness. Dito de maneira lapidar, disease é a doença do médico, illness a doença do paciente e entre as duas existe uma importante distorção. Eu queria entender as urgências e as emergências tanto do ponto de vista dos médicos quanto dos leigos. Eu sempre escutava dos médicos: "Ah, mas isso não é urgência”, “Ah, $80 \%$ dos atendimentos não são urgências”. Eu, como antropóloga e curiosa, perguntava-me: se $80 \%$ das pessoas vão para o pronto-socorro e não se trata de urgência para os médicos, o que é urgência para essas pessoas?

Como na França não havia distinção entre urgência e emergência, isso foi ótimo para eu aprofundar essas duas noções no trabalho de campo brasileiro. Procurei explorá-las a partir de duas grandes perspectivas que não se recobrem, a dos usuários da rede pública de atendimento às urgências/emergências e a dos profissionais que nela atuam, tanto a equipe de saúde propriamente dita quanto os não médicos, vigilantes, porteiros, recepcionistas, atendentes das centrais, motoristas de ambulância. A literatura médica tem a ambição de definir essas noçóes, mas quanto mais ela tenta estabelecer recorte, menos ela consegue, porque, por exemplo, para se caracterizar urgências são feitas referências às emergências, ou seja, "emergência é uma urgência mais grave". Enfim, havia muita coisa interessante também do ponto de vista estritamente médico e pude perceber que ele variava. Atentei, então, para quais critérios eram apreciados pelos médicos ao considerarem um caso mais urgente do que outro.

Eu trabalhei muito a percepção dos médicos, mostrando que eles consideravam não só elementos técnicos, mas pessoais e ideológicos. É aí que o trabalho de campo ganha relevância, pois não se podem trabalhar tais percepçôes sem observaçôes. Há sinais sutis que não se identifica perguntando-se diretamente ao médico se algo é urgente ou não. É bem melhor observar por que tipo de caso a equipe médica mais se mobiliza, quando os gestos ficam mais rápidos, pois, ao contrário do que se imagina, o mundo da urgência e da emergência é lento. Quase nada acontece e, de repente, há uma aceleração.

Interessava-me também a visão dos pacientes, justamente porque ela é normalmente desacreditada do ponto de vista dos médicos e é desconhecida. Por fim, percebi que, para alguém chegar a ser atendido era preciso passar por várias apreciaçôes, como opiniôes de recepcionistas e motoristas. Afinal, me dei conta de que a apreciação da urgência era forjada por "não médicos" e que os profissionais de saúde eram os últimos na produção de uma cadeia de significados. 
Para voltar à pergunta, Marília foi um lugar ideal porque, na imensa cidade de São Paulo, eu via os casos aparecerem nos prontos-socorros, mas eu estava longe das centrais de atendimento, de modo que eu não podia observar as reaçôes dos atendentes, comparar o conteúdo das falas ao telefone com a realidade das situaçóes no local. Em Marília, eu podia ficar na central de atendimento, sair com o motorista, ir à casa da pessoa a ser atendida, acompanhá-la até o hospital universitário e voltar para a central, ou mesmo permanecer no hospital. Eu podia acompanhar todo o processo e isso era extremamente rico. Enfim, por tudo isso eu escolhi Marília e também pelo interesse que eles tinham na pesquisa, a qual, quando se tornou livro, foi prefaciada por Cecília Dellatorre.

Cabe também pontuar meu interesse pela homeopatia. Eu já a tinha identificado nos espaços da umbanda e do kardecismo. Estudei a implantaçâo e arranjos da homeopatia na sociedade brasileira, a partir de uma problemática de difusão das medicinas em um contexto geral de globalização ${ }^{12}$, contando para isso com o antropólogo belga Olivier Schmitz ${ }^{13}$, que também estudou a homeopatia, a partir do mesmo enfoque, na Índia. Trabalhamos juntos, a partir de uma perspectiva comparada, o que se justificava pelo fato de que uma das caraterísticas mais marcantes dessa medicina é o fato de que ela se espalhou muito cedo pelo mundo. Desde a primeira metade do século XIX, ela atravessou as fronteiras da Alemanha e da Europa para se difundir nas Américas e na Ásia. Nós fizemos um projeto que objetivava investigar as adaptaçóes da homeopatia às várias sociedades pelas quais ela se difundiu, quase na mesma época em que ela nasceu na Alemanha. Trabalhei nisso, durante alguns anos, em São Paulo, no momento em que uma das grandes fabricantes mundiais de remédios homeopáticos tinha aberto uma filial na capital. Através dessa fabricante, questionei qual concepção de homeopatia estava em implantação e como o campo homeopático brasileiro reagia em relação a isso, em nome de outras concepçóes de homeopatia.

\section{E quanto às suas pesquisas mais recentes?}

São duas as pesquisas que recentemente ampliaram e enriqueceram meu campo de interesses. Uma relação de continuidade com as anteriores é certamente difícil de perceber. Há essa pesquisa sobre os jurados do Tribunal do Júri da França, que desenvolvo desde 2009, em colaboração com meu colega Aziz Jellab, sociólogo do Centre de Recherche 
Individus, Épreuve et Société - Ceries. E há outra, realizada desde 2012, no âmbito do programa de pesquisa franco-brasileiro Coqueiral ${ }^{14}$, voltada para o cotidiano de moradores da Região Metropolitana de Recife, confrontados com a degradação crescente dos recursos hídricos.

Como se deu a pesquisa sobre os jurados no Tribunal do Júri francês?

$\mathrm{Na}$ trajetória de um pesquisador, os acontecimentos da vida pessoal também podem influir, chamando repentinamente a atenção para fenômenos que podem se transformar em objetos de pesquisa. São oportunidades. Foi o que aconteceu comigo nessa pesquisa. Seu impulso inicial decorreu de minha participação como jurada no Tribunal do Júri de Douai, uma cidade do norte da França, em 2008. Foi uma participação totalmente inesperada que me tirou da rotina durante três semanas, algo que pode acontecer com qualquer cidadáo francês com pelo menos vinte e três anos de idade, caso seja sorteado a partir das listas eleitorais. $\mathrm{Na}$ França só se pode ser jurado mediante esse tipo de sorteio, embora, depois, haja ainda outros sorteios até que alguém chegue a desempenhar o papel de jurado em um processo. Enfim, foi uma oportunidade ímpar observar algo que está em parte inacessível ao público em geral. Somente sendo jurado se participa de certos momentos e se transita por certos lugares como os bastidores do Tribunal do Júri, a sala dos jurados e o momento da deliberação, quando juízes profissionais e leigos debatem e decidem se há culpa e, em caso afirmativo, qual deve ser a pena.

O fato de eu não ter formação em antropologia do direito e nenhum trabalho anterior nessa área não me impediu de aproveitar essa experiência de jurada com os olhos e as preocupaçóes de uma antropóloga, ainda mais sendo uma antropóloga que havia estudado religião durante anos. Em meus primeiros momentos, na sala de julgamento, tive a sensação de estar em um universo ao mesmo tempo desconhecido e familiar. Desconhecido por que era cifrado e nele eu precisava encontrar o meu lugar, construir meu papel e as minhas relaçóes com os outros; eu me sentia sem referências. Familiar porque a dimensão altamente codificada, ritualizada, espetacular e dramatizada de tudo me remetia aos terreiros. Só faltava o cheiro de incenso! Estou brincando, mas fazer uma leitura simbólica do Tribunal do Júri foi inevitável. 
Portanto, considerando a excepcionalidade da situação na qual eu me encontrava, fui ao fórum preparada para qualquer desdobramento em termos de pesquisa. Eu pensava: "vou observar essa situaçáo peculiar náo como um observador que participa, mas como um participante que observa”. Eu não sabia se ia dar certo, pois imaginava que o papel de jurado exigiria muito em termos de aprendizagem, de concentração, de engajamento e mesmo emocionalmente. Mas isso tudo não impossibilitou nem minha participação como jurada nem minhas observaçóes como antropóloga. Aziz Jellab me ajudou a objetivá-las e fizemos uma pesquisa inédita e original sobre os jurados na França. Antes disso, os jurados eram atores desprezados nos trabalhos sobre o Júri francês, seja pela sociologia, seja pela antropologia, seja ainda por historiadores do direito. Como esses cidadãos leigos se socializam no Tribunal do Júri? Como eles vivem esse parênteses que desestabiliza seu cotidiano e os obriga a fazer uma aprendizagem rápida de um papel até então desconhecido? Essas foram as primeiras perguntas que nortearam a pesquisa ${ }^{15}$. Mais recentemente, ampliamos a pesquisa para uma comparação com os jurados e o Tribunal do Júri brasileiros, juntamente com Ana Lúcia Pastore Schritzmeyer ${ }^{16}$ que, desde sua tese de doutorado, se dedica a uma abordagem antropológica do Tribunal do Júri.

Pelo seu objeto, essa pesquisa se inscreve na antropologia do direito, mas eu não diria que sou uma antropóloga do direito. Não sou especialista nessa área e não a domino. O que une todas as minhas pesquisas, qualquer que seja a área da antropologia em que elas se inserem, são, fundamentalmente, o Brasil, o trabalho de campo, a observação participante e a etnografia.

Foi assim com a pesquisa em Recife. Os hidrogeólogos e hidroquímicos franceses do Bureau de Recherches Géologiques et Minières, BRGM, não me procuraram porque eu era especialista em questóes relativas ao acesso à água ou à antropologia do meio ambiente ou ainda à uma antropologia da natureza, mas porque eu sou antropóloga. Eles precisavam de uma brasilianista, com experiência de pesquisa no Brasil, preparada, como antropóloga, para explorar a dimensão cultural da água no país. Eu entrei na pesquisa por vários motivos: a oportunidade de participar de um projeto interdisciplinar e instigante; estar em um projeto que julgava importante para o presente e o futuro de um recurso bastante deteriorado e ameaçado nessa cidade brasileira; por acreditar na importância da abordagem antropológica para o entendimento da situação e, por fim, pela oportunidade de conhecer uma cidade e uma região do Brasil na qual eu nunca trabalhara. Havia também a 
possibilidade de experimentar a fotoetnografia e uma nova forma de disseminação dos resultados da pesquisa através de exposiçóes fotoetnográficas. Durante os quatro anos dessa pesquisa, eu e Tadeu Giglio, antropólogo e fotógrafo, fizemos um trabalho de campo aprofundado em alguns bairros de Recife, abordando representaçóes, práticas e usos da água.

Desde o início, minhas pesquisas implicaram colaboraçôes com outros campos do saber, tanto com disciplinas das ciências sociais e humanas (sociologia, geografia, direito, ciência politica), quanto com disciplinas das ciências médicas, hidrogeologia e hidroquímica. Começar com pesquisas no campo da antropologia da doença convenceu-me da importância da integração de diversas perspectivas para a compreensão de nossos objetos de estudo.

E como é a aceitação de uma trajetória como a sua pela academia francesa?

$\mathrm{Na}$ França, como no Brasil, não somos encorajados, enquanto antropólogos, a atuar de modo muito interdisciplinar. Lá se recomenda a formação continuada em um campo específico. A liberdade que tomo em relação a essa prescrição acaba desenhando um perfil de pesquisadora nada ortodoxa. Pode ser que eu pague um certo preço por isso, pois, academicamente, é difícil ser classificada como tendo uma "trajetória diversa". Tive e tenho interlocutores muito diversos que geralmente só conhecem uma faceta da minha produção. Isso pode criar dificuldades, mas nunca foi um obstáculo. Tenho uma sensação até contrária. Uma coisa é certa: encontrei uma maneira de praticar a antropologia que me convém e isto sempre renova meu entusiasmo pela pesquisa, o que se faz crucial, pois o trabalho de campo exige muito e é muito desgastante.

Você nos contou que veio pesquisar no Brasil por conta de seu interesse pela umbanda. Mas, em outra oportunidade, também nos contou que tinha interesse pela América Latina e escolheu o Brasil. O que influenciou essa escolha?

Desde pequena, eu tinha a vontade de conhecer a América do Sul. Era um objetivo a atingir, apesar de a minha história familiar em nada se relacionar a esse continente. Ele era para mim uma terra longínqua e, para alcançá-la, eu sabia que teria que me empenhar. 
Na minha infância, no início dos anos 70, falava-se muito da América do Sul na França, das ditaduras e, especialmente, da ditadura no Chile de Pinochet. Falava-se do golpe, dos assassinatos, das torturas, das pessoas encarceradas nos estádios. Tenho a lembrança viva e horrorizada desses acontecimentos. Havia também os exilados chilenos nas praças francesas, tocando música. Sentia muita admiração e compaixão por eles e adorava o que tocavam. $\mathrm{Na}$ adolescência comprei uma flauta e um método para apreender sozinha. Guardo os dois até hoje. Os meus pais eram de esquerda, suponho que se devia falar muito sobre tudo isso na minha casa. Meu pai tinha ido à Cuba, em 1970, e voltou com muitos cartazes, com os quais recobri as paredes do meu quarto. Ele era professor de filosofia. Suponho que isso me marcou muito. Mas esse "um dia irei à América do Sul” deve ter sido despertado pelo Chile. Quis aprender espanhol no colégio, fiquei encantada com a língua e também com meu professor. Enfim, muitas coisas convergiram. A minha sorte foi que, quando eu estava estudando antropologia, em Aix-en-Provence, no terceiro ano, apareceu um novo curso, o "Magistère en Sciences Sociales" do qual já falei, aplicado a várias áreas culturais de especialização. Entre elas havia a dos "países asiáticos", com a China, a dos "países árabes", com o Egito, e a da "América Latina", com o Brasil. As únicas pré-condiçóes para passar na entrevista de seleção era estar no terceiro ano de uma disciplina de ciências sociais e ter aprendido espanhol na escola. Esse magistério foi fundamental para a formação de quem desejava fazer antropologia na América do Sul. Graças a ele também aprendi português, de maneira intensiva, pois as aulas de geografia, civilização, história, política e economia eram ministradas em português do Brasil, além do que tínhamos que falar e apresentar os trabalhos em português. Quando cheguei a São Paulo, pela primeira vez, no final do primeiro ano desse magistério, para um estágio linguístico de dois meses na USP, cheguei com um conhecimento razoável do Brasil e da língua. Suponho que se tivesse surgido a Argentina no meu caminho rumo à América do sul, hoje eu estaria pesquisando lá. Mas o Brasil foi o meu destino.

Descobrindo São Paulo, apaixonei-me e fiquei deslumbrada com o gigantismo da cidade, seu ritmo acelerado, seu barulho ininterrupto. Eu subia, à noite, até o alto do prédio em que eu morava, no centro da cidade, para escutar a respiração do monstro e olhar suas luzes. Sentia muito prazer e proximidade nas minhas relaçóes com os outros, o que me cativou, pois não imaginava que seria tão fácil. Era tudo novo para $\mathrm{mim}$, sem contar a umbanda e seus terreiros! Uma vez no Brasil, não demorei a começar meu trabalho de 
campo, mas nada do que havia previsto, de início, deu certo. Não fiquei com a família que deveria me hospedar, pois a estudante que se ofereceu para me receber tinha fugido com o namorado e eu não quis morar sozinha, em um apartamento imenso e bastante escuro, com um casal de idosos. Fui morar na casa do primo do meu professor de português de Aix-enProvence, a quem devo uma formidável iniciação à música popular brasileira. $\mathrm{O}$ estágio linguístico também não aconteceu, pois houve um problema de organização, o que me liberou, durante dois meses, para o tralhado de campo que eu tinha que fazer para a pesquisa de quarto ano, chamada "Maîtrise d'anthropologie". O campo ocorreu entre julho e agosto de 1987. Defendi esse primeiro trabalho, sobre umbanda, em setembro de 1988. Chamava-se "L'Umbanda dans le champ religieux brésilien: Tranformation d'un culte périphérique em église établie". A tese de doutorado foi defendida em janeiro de 1998.

Além de estudos sobre o Brasil, no Brasil, destaca-se em sua trajetória o uso de várias metodologias advindas da antropologia. Como se deu a escolha pela antropologia?

Estudei primeiro sociologia. Quando entrei na universidade, eu não conhecia a antropologia e só a descobri em uma aula de iniciação à pesquisa. A sociologia já tinha sido reveladora para mim, com a leitura d'O suicídio, de Durkheim. Descobrir que em um ato tão pessoal como esse, que parece exclusivamente restrito à esfera íntima e psicológica, também havia fatores sociais e coletivos, como o meio, o momento do ano, do dia e da vida social, foi uma dessas revelaçóes que marcam, pois abrem os olhos e o mundo. Eu tinha 18 anos, na época, e me apaixonei pela sociologia. Mas, a partir do segundo ano, lembro que me tornei crítica, insatisfeita com a abordagem quantitativa, a qual eu achava reducionista. Ficava incomodada e até indignada com as generalizaçóes que amputavam certos aspectos do real, sua complexidade, sua pluralidade, simplificando-o, empobrecendo-o, forçando ou truncando as realidades estudadas. Experimentei isso de maneira aguda nas pesquisas coletivas que fazíamos para nos formar. Então, contei com a sorte, mais uma vez. Nesse mesmo ano, em uma aula optativa, descobri a antropologia, sua abordagem qualitativa e o trabalho de campo. Eu havia encontrado meu método! Esse que pressupóe empatia e compreensão, interação e participação, um conhecimento que se constrói a partir da experiência da alteridade. Esse método me pareceu encarar a diversidade, a heterogeneidade e a complexidade do mundo com precisão e fineza. Não se trata de algo fácil, mas, com ele, 
pelo menos é possível se sentir fiel às realidades e às pessoas com as quais se produz conhecimento. Conhecimento que, se divulgado, pode contribuir para a imagem que se dá dos outros, o que implica uma tremenda responsabilidade. O viés da generalização é a simplificação e, portanto, uma possível traição. Acho que a etnografia, feita rigorosamente e com o tempo necessário, nos dá garantias contra isso. Resumindo, no final do segundo ano de sociologia fui para a antropologia, o que era, aliás, um percurso clássico, na época, pois o curso só começava a partir do terceiro ano.

Isso nos leva à próxima pergunta, sobre a utilização de recursos visuais nos seus trabalhos, porque isso também chama a atenção em sua trajetória. Como se deu seu contato com o campo audiovisual, o uso de imagens, não somente a fotografia, mas também a produção de documentários?

No laboratório de pesquisa onde preparei minha tese, chefiado por Jean Benoist, havia uma filmadora. Apesar disso, não se incentivava o uso de imagens em pesquisas, não se falava em antropologia visual nesse laboratório e nada me foi dito a respeito de antropologia visual durante toda minha formação em ciências sociais. A reflexão sobre o uso de imagens não existia. Mas havia uma filmadora à disposição. Esse é o primeiro ponto. O segundo é que durante minha pós-graduação, um antropólogo do Museu de História Natural de Paris, um africanista, médico, Alain Epelboin, que usava vídeo em campo, deu uma palestra relacionada à questão da bruxaria. Ele chamou bastante minha atenção, pois eu já usava a máquina fotográfica em campo, mas nunca tinha pensado em também filmar. Não me lembro bem, mas, talvez no primeiro campo que fiz para a realização da tese, pedi a filmadora emprestada. Aí vim ao Brasil com ela, sem nenhuma formação técnica e com reflexóes incipientes sobre seu uso. $\mathrm{O}$ óbvio para mim era que esse uso, no trabalho de campo, estava diretamente ligado à atividade de observação e que ele multiplicaria a minha capacidade descritiva, mais que as fotografias, pois me permitia gravar sons, falas, músicas e movimentos.

Relacionado a esse primeiro uso da filmadora em campo, me vem à lembrança o receio de que ela fosse roubada. A filmadora era grande, era uma filmadora de ombro. No final dos anos 80 , o material não tinha chegado à miniaturização que conhecemos hoje e eu ia aos terreiros de ônibus. Andava com a câmera na rua, dia e noite, numa sacola de 
lixo preta, que foi a solução que encontrei para não chamar a atenção. Era muito relevante para mim filmar em campo. A partir dessa primeira experiência, nunca mais parei. Desde então, reafirmou-se meu interesse por imagens e confirmou-se sua importância como um instrumento de investigação, um modo de escritura, um meio de comunicação - através do filme etnográfico notadamente -, e um instrumento metodológico. Mas, com o tempo, minha prática e minhas intençôes se transformaram ao gravar imagens em campo.

No início, o uso da filmadora me parecia muito valioso em relação aos fenômenos que eu estudava: universos religiosos com suas cerimônias, suas consultas, rituais dominados pelo movimento, danças, possessóes, toda a gestualidade. Eu podia gravar e rever, quantas vezes quisesse, as expressóes de corpos e rostos. Depois de um tempo, me dei conta de que essas gravaçôes também registravam meu modo de observar e minha inserção no campo. Mas eu ainda náo explorava essa perspectiva reflexiva naquela época. Até o trabalho sobre urgência e emergência e o filme Urgences $^{17}$, a filmadora representou para mim um instrumento de pesquisa que fabricava dados audiovisuais. Um instrumento muito vantajoso e completo. Tanto na intenção quanto na utilização, as imagens que eu fazia almejavam ser o que André Leroi-Gourhan chamou de "notas cinematográficas", em seu famoso artigo de $1948^{18}$. Eu as utilizava mais para lembrar o que havia vivido em campo. Mesmo quando as mostrava, por considerar que tinham forte valor descritivo, eu considerava que elas não se bastavam e fazia comentários. Eu também sempre copiava esse material para meus interlocutores no campo, pois era uma maneira de devolver-lhes algo em troca do que haviam me dado. Até hoje faço isso. A maioria dessas imagens permaneceu em estado bruto e, quando foram montadas, isso foi feito grosseiramente para a projeção em seminários, aulas, conferências. A própria linearidade dos rituais servia de fio condutor.

Aliás, Alain Epelboin, alguns anos depois do primeiro encontro que relatei, sabendo que eu estava com um material audiovisual sobre umbanda, me convidou a apresentá-lo no seminário "Santé, maladie, malheur" que ele dirigia no Museu de História Natural de Paris. Lembro que ele me recebeu em seu escritório, do qual quase não saímos, durante dois dias, para montar o que seria apresentado. Depois chamei esse documento audiovisual de Imagens do ritual da umbanda em São Paulo, Brasil. 1. Sessão da direita no Duílio ${ }^{19}$. Produzi outro documento, no mesmo ano: 2. Sessão da esquerda na Dona Dolores ${ }^{20}$, filmado em um terreiro de Taboão da Serra. Tudo foi muito instigante: o trabalho de montagem, as 
conversas, os debates em torno das imagens do ritual e a análise. Foi uma experiência formadora que me deu mais confiança para usar a câmera e as imagens. Entretanto, durante anos, não pensei que podia fazer filmes.

Esse projeto se fez em resposta a várias constataçóes desagradáveis que se acumularam no que diz respeito ao efeito das imagens. Quando eu mostrava as imagens de umbanda era sempre com o intuito de aproximar as pessoas de universos "exóticos", alheios a elas, universos dos quais eu havia participado. Eu queria oferecer elementos descritivos para as pessoas não imaginarem coisas, práticas e outras pessoas somente a partir de suas próprias categorias. Mas, em várias projeçôes, constatei que, ao invés de minhas imagens aproximarem o público dos universos exóticos elas, em estado bruto, produziam uma espécie de dramatização da diferença e confirmavam o sentimento de estranheza dos espectadores e até mesmo os seus preconceitos.

\section{Onde essas imagens foram exibidas?}

Em aulas, congressos e seminários que, de alguma forma, se relacionavam com a questão da religião, da medicina, da cura e da dimensão terapêutica das religiôes. $\mathrm{O}$ mesmo já tinha acontecido com as imagens em estado bruto de outros pesquisadores, projetadas nos mesmos contextos. Muitas imagens mostravam rituais, práticas de cura, transes xamânicos, possessóes, etc. E eu escutava certos comentários que deixavam claro que, do ponto de vista dos espectadores, essas imagens náo lhes proporcionavam reflexóes relativistas como: "realmente somos apenas uma amostra singular da humanidade"; "existem tantas outras interpretaçôes disponíveis para dar sentido e inteligibilidade ao mundo e ao que acontece nele”. Para certas pessoas, as imagens só confirmavam que “ainda” existiam práticas e sociedades primitivas, atrasadas, ignorantes e estúpidas.

Você acredita que o texto etnográfico e a descriçâo talvez sejam opçóes comunicativas menos drásticas que as imagens?

Pode ser, mas depende das palavras, das frases e das construçóes semânticas escolhidas. Imagens são muito evocadoras, sugestivas e polissêmicas. Não que as palavras não o sejam, 
mas nas ciências, para limitar essa polissemia, criaram-se os conceitos. Mas como criar um conceito para uma imagem? Como definir e fixar seu conteúdo para que todos entendam, mostrem e falem a mesma coisa? Isso não existe! $\mathrm{O}$ meu entendimento, hoje, sobre aquelas reaçóes que mencionei, é que faltou, da minha parte, um questionamento, uma reflexão sobre as modalidades de conhecimento e de mise en scène do real operantes nos documentos audiovisuais que eu mostrava. Eu fazia um uso bastante ingênuo das imagens. Não é cabível transportar imagens brutas, feitas com a intenção de coletar dados para uma pesquisa, a contextos em que não se trata mais de reunir dados, mas de comunicar resultados. Tudo muda: o estatuto das imagens, as intençôes e os destinatários. Não basta ter uma intenção na cabeça ao mostrar imagens para fazer com que essa intenção se realize: é preciso elaborar uma construção.

Mas tudo isso foi uma boa experiência, pois esse sentimento de desconforto moral me levou a filmar a partir de uma nova perspectiva: não mais para coletar dados úteis às minhas pesquisas, mas para fazer filmes que existissem e fizessem sentido por si sós, permitindo a outras pessoas acessar certas realidades e vivências que meu trabalho de antropóloga me leva a explorar e apreender de dentro do campo etnográfico; documentários etnográficos portanto, não explicativos ou didáticos, mas compreensivos, que proporcionam um sentimento de encontro com os universos, as pessoas e as práticas exibidas. Aí as perguntas que surgiram foram: como conseguir isso com sons e imagens? O que mostrar da realidade de referência? O que colocar em imagens e em relato? Escrevi um artigo, em português ${ }^{21}$, que enfoca as respostas que encontrei para essas questóes na produção de Nice, bonne au $B_{r e ́ s i l^{2}}$. Nele eu falo sobre as escolhas de produção para comunicar o que eu desejava do trabalho de Nice, empregada doméstica, a partir de sua própria visão e vivência. Ao filmarmos e editarmos, fazemos inúmeras escolhas para atingir nossos objetivos e realizar nossas intençóes. Quando me dei conta disso, passei realmente a fazer filmes e a encarar esses filmes como textos audiovisuais.

Sobre isso é possivel lembrar de Margareth Mead e Bateson, em "Bathing Babies in Three Cultures", documentário em que ela explica e narra, enquanto as imagens passam...

Sim. Aliás, a ambição que tenho, em meus filmes, é não usar voz off f $^{3}$, não porque eu seja contra: é uma possibilidade, mas ela não serve para as minhas intençôes. Desejo de dentro 
do mundo no qual eu mergulho, o espectador possa apreciar com liberdade a significação dos gestos, palavras e situaçóes representadas. Para conseguir isso, não posso recorrer a uma voz off. A própria montagem há de ser o comentário. É assim nos filmes de Frederick Wiseman, por exemplo.

E para novamente registrar o quanto eu não sou ortodoxa, há três anos eu deixei uma cadeira de antropologia na Universidade de Lille, a qual eu ocupava desde 1998, e disputei uma de sociologia visual na Universidade de Poitiers, onde agora trabalho. Vagas com esse perfil são raríssimas, então decidi me inscrever no concurso. É uma oportunidade que me permite, com mais legitimidade e mais recursos materiais, dedicar-me à produção de imagens e filmes.

Para finalizar, gostariamos que você mencionasse seus projetos futuros.

Estamos finalizando a pesquisa realizada em Recife e, nesta fase de análise dos dados e divulgação dos resultados, temos alguns produtos em elaboração: um livro com Paul Cary ${ }^{24}$ e Ana $\mathrm{Melo}^{25}$ (os dois pesquisadores que cuidaram da vertente sociológica de Coqueiral, focada na governança da água); a sistematização das fotos de autoria de Tadeu Giglio; $\operatorname{artigos}^{26}$; um documentário; e realização de uma exposição fotoetnográfica itinerante na França ${ }^{27}$.

Vou continuar me dedicando à pesquisa comparativa entre jurados brasileiros e franceses, com Ana Lúcia Pastore Schritzmeyer e Aziz Jellab, a qual, por enquanto, não deslanchou como gostaríamos, por conta de outros compromissos de nós três. Não é fácil levar uma pesquisa adiante, em meio a várias atividades e tarefas acadêmicas... É preciso ter muita motivação. Aliás, aproveitei esta minha viagem a São Paulo, para participar do IV Encontro Nacional de Antropologia do Direito (Enadir), e assisti a algumas sessóes de julgamento nos Tribunais do Júri do Fórum Criminal Ministro Mário Guimarães. Eu já havia assistido a outras, em Curitiba, mas em caráter exploratório, para verificar a pertinência da comparação França-Brasil. Preciso intensificar essa imersão. Como vocês podem perceber, projetos não faltam.

Gostariamos de finalizar, agradecendo, em nome de toda a equipe do Nadir e do Departamento de Antropologia da USP, a sua disponibilidade e disposiçāo para conversar conosco. 


\section{Notas}

1 Carmen Fullin é doutora em Antropologia Social (PPGAS/USP), professora da Faculdade de Direito de São Bernardo do Campo e pós-doutoranda na Escola de Direito de São Paulo da FGVSP; Juliana Tonche é doutora e pós-doutoranda em Sociologia pela Universidade de São Paulo; Maria Luisa Scaramella é doutora em Ciências Sociais pela Universidade Estadual de Campinas (Unicamp) e pós-doutoranda em Antropologia na Universidade de São Paulo. Ana Lúcia Pastore Schritzmeyer é professora do Departamento de Antropologia da Universidade de São Paulo. Todas integram o Núcleo de Antropologia do Direito (Nadir - USP).

2 Peirano, Mariza. 2014. "Etnografia não é Método”. Horizontes Antropológicos, Porto Alegre, ano 20, n. 42 , p. 377-391.

3 Liana Trindade é professora aposentada do Departamento de Antropologia da Universidade de São Paulo. Em 1980 concluiu o doutorado em Ciência Social, intitulado Exu: símbolo e função, na Universidade de São Paulo.

4 Para saber mais: Bastide, Roger. 1973. "A macumba Paulista”. In Estudos afro-brasileiros. São Paulo, Ed. Perspectiva, pp. 193-247; 1971. As religiões africanas no Brasil. São Paulo, Ed. Pioneira; 1967. "Le Spiritisme au Brésil". Archives des Sciences Sociales des Religions, Paris, n 24: 3-16.

5 Ortiz, Renato. 1991. A morte branca do feiticeiro negro. Umbanda e sociedade brasileira. São Paulo, Ed. Brasiliense.

${ }^{6}$ Giglio-Jacquemot, Armelle. Guides et Médiums au secours des Hommes - Étude des représentations et des pratiques liées à la maladie et à son traitement dans l'umbanda à São Paulo (Brésil). Lille, ANRT, 1998, 598 p. Tese defendida na Université d’Aix-Marseille, França. Acessível online no site da Comunidade virtual de Antropologia: http://www.antropologia.com.br/divu/colab/d18-agjacquemot.pdf.

7 Entre outras publicações: Giglio-Jacquemot, Armelle. 2009. "O médico falou que eu não tinha nada: a Umbanda à escuta de seus doentes". In Mercer, Vânia Regina (org.). Travesseiro de pedra Entretecendo discursos sobre as escutas de doentes. Curitiba, Editora da Universidade Federal do Paraná, pp. 153-164; 2006. "Médicos do Astral e médicos da Terra - As relações da Umbanda com a biomedicina”. Mediações-Revista de Ciências Sociais, Dossiê Antropologia da Saúde, Londrina, Universidade Estadual de Londrina, vol.11, n. 2: 83-98; 2001. "L'Umbanda: Une Religion stigmatisée". Africultures, Dossier Brésil Noir, n 34: 25-30; 1998. "Umbanda et maladie: La Distinction maladies matérielles/maladies spirituelles". Cahiers du Brésil Contemporain, Numéro Spécial Religions : orthodoxie, hétérodoxie et mysticisme, Paris, Ehess, n. 35-36: 105-136; 1996. "L'Umbanda et ses malades dans le champ médical brésilien". In Benoist, Jean (org.). Soigner au pluriel, Paris, Karthala, pp. 143-170; 1995. "La Perception de la folie dans l'umbanda”. In Reverzy, J.F. (org.). Tet'vid. Un Autre regard sur la dépression, vol. II, Collection Anthropologie et Psychanalyse, Saint Denis de La Réunion, L’Harmattan/Grand Océan, pp. 173-181.

8 Jean Benoist é professor aposentado da Universidade de Montréal e da Universidade Paul Cézanne de Aix-Marseille. Uma parte importante de suas pesquisas dizem respeito à antropologia médica, por ele lecionada em Aix-en-Provence, de 1981 a 2000.

9 Para saber mais: Giglio-Jacquemot, Armelle. 2005. Urgências e emergências em saúde: perspectivas de 
profissionais e usuários. Coleção Antropologia e Saúde. Rio de Janeiro, Editora Fiocruz; 2005. "A presunção de urgência e seus índices nas apreciações dos profissionais de saúde do prontosocorro de um hospital universitário brasileiro". Política e Trabalho - Revista de Ciências Sociais, João Pessoa, Universidade Federal da Paraíba, n. 23: 77-90.

10 Serviço de Atendimento Móvel de Urgência.

11 Maria Cecília Cordeiro Dellatorre é docente da Faculdade de Medicina de Marília (Famema), atualmente trabalhando na área da epidemiologia.

12 Para saber mais: Giglio-Jacquemot, Armelle. 2011. "Unicistes versus pluralistes: l'Homéopathie brésilienne à l'ère de la globalisation". Anthropologie et santé [Online], 3. Disponível em: http:/ / anthropologiesante.revues.org/767.

13 Olivier Schmitz é pesquisador do Centre d'Etudes Sociologiques, Facultés Saint-Louis, Bruxelas.

${ }^{14}$ Coqueiral é o acrônimo de “COntraintes sur la Qualité de l'Eau dans l'environnement urbaIn de Recife. Comment faire face à la sALinisation et à la contamination des eaux souterraines dans les contextes de changements environnementaux planétaires et sociétaux?". Tratou-se de um projeto de pesquisa iniciado em 2012, pluridisciplinar, com quatro parceiros franceses e cinco brasileiros, financiado por três agências: a Agence Nationale de la Recherche - ANR, a Fundação de Amparo à Pesquisa do Estado de São Paulo - Fapesp, e a Fundação de Amparo à Ciência e Tecnologia de Pernambuco - Facepe.

15 Para saber mais: Giglio-Jacquemot, Armelle. 2015. "Stratégies d'enquête en milieu hautement légitime. À Propos d'une recherche sur les juges et les jurés populaires en cour d'assises”. Recherches sociologiques et anthropologiques [Online], 46 (1): 167-181. Disponível em: http://rsa.revues.org/1450; 2012. Des Citoyens face au crime - Les Jurés d'assises à l'épreuve de la justice, Toulouse, Presses Universitaires du Mirail; 2012. "Les Jurés populaires et les épreuves de la cour d'assises: entre légitimité d'un regard profane et interpellation du pouvoir des juges". L'Année sociologique, n. 1, vol. 62: 145-193; 2012. "Des Profanes en justice. Les Jurés d'assises, entre légitimité et contestation du pouvoir des juges". Politix, n 97: 149-176; 2012. "Les Jurés à l'épreuve des assises: description et portraits d'une expérience marquante". Les Cahiers de la Justice, Dossier "Regain ou déclin du jury en Europe", n. 1: 31-44; 2011. "Quand les citoyens rendent la justice". Ceras - revue Projet [Online], n. 323: 11-16. Disponível em: http://www.ceras-projet.com/index.p....

${ }^{16}$ Schritzmeyer, Ana Lúcia Pastore. 2012. Jogo, ritual e teatro: um estudo antropológico do Tribunal do Júri. São Paulo, Editora Terceiro Nome.

17 Urgences, couleur, 2002, 59’, DVD. Versão original em português, subtítulos em francês. Coprodução Armelle Giglio-Jacquemot/Université de Lille 3.

18 Leroi-Gourhan, A. 1948. "Cinéma et sciences humaines: Le Film ethnographique existe-t-il?”. La Revue de géographie et d'ethnologie, Paris, n. 3: 42-50.

${ }_{19}$ Images du rituel d'umbanda à São Paulo, Brésil-1. Cérémonie de la droite chez Duílio, 1995, 58', Maquette Vidéo 8. Versão original em português. SMM Centre de publications audiovisuelles anthropologiques, CNRS-MNHN, Paris.

${ }^{20}$ Images du rituel d'umbanda à São Paulo, Brésil - 2. Cérémonie de la gauche chez. Dona Dolores, 1995, 28', Maquette Vidéo 8. Versão original em português. SMM Centre de publications audiovisuelles anthropologiques, CNRS-MNHN, Paris.

${ }^{21}$ Giglio-Jacquemot, Armelle. 2014. "Descritividade e emicidade do documentário: as escolhas de 
realização de um filme sobre o trabalho doméstico". In Ferraz, A.L.C. e Mendonça, J.M. de (orgs.), Antropologia visual: perspectiva de ensino e pesquisa [Online], Brasília, ABA, pp. 305-331. Disponível em: http://www.portal.abant.org.br/index.php/bibliotecas/livros.

22 O documentário foi premiado no Festival Internacional do Filme de Pesquisadores sobre as Escravidões em Lyon, em 2011 e indicado para vários festivais na França e no Brasil.

${ }^{23}$ Nota explicativa: voz off corresponde ao narrador onisciente e onipresente.

${ }^{24}$ Paul Cary é professor de sociologia na Universidade de Lille Nord de France, com várias pesquisas no Brasil.

${ }^{25}$ Doutoura em "géographie, aménagement et urbanisme", Ana Melo é engenheira de pesquisa na Maison Européenne des Sciences de l'Homme et de la Société de Lille.

${ }^{26}$ Em 2015, foi publicado: Cary, Paul; Giglio-Jacquemot, Armelle; Giglio, Tadeu; e Melo, Ana. 2015. "Vivre avec la pénurie d'eau à Recife. Déni public, alternatives privées". Espace populations sociétés [Online], 2-3. Disponível em: http://eps.revues.org/5824.

27 A mostra itinerante TER AGUA. Uma fotoetnografia da água do cotidiano no Recife, foi lançada em julho de 2015 por ocasião da Conferência Final do Projeto Coqueiral em Recife e tem se deslocado por vários bairros, com previsão de percurso por outras cidades do Nordeste e Sudeste. 